DOI: https://doi.org/10.32839/2304-5809/2021-4-92-56

удК 349.4.34

Кушнір B.B.

Національний юридичний університет імені Ярослава Мудрого

\title{
ОКРЕМІ АСПЕКТИ РОЗГЛЯДУ ЗЕМЕЛЬНИХ СПОРІВ, ЩО ВИНИКАЮТЬ ПРИ ФОРМУВАННІ ЗЕМЕЛЬНИХ ДІЛЯНОК
}

\begin{abstract}
Анотація. Стаття присвячена дослідженню окремих аспектів розгляду земельних спорів, які виникають при формуванні земельних ділянок. Розглянуто поняття земельної ділянки і відповідно до нормативного визначення зазначеного поняття виділено його основні ознаки. Аналізуючи формування земельних ділянок, автор зазначає про наявність різних процедур, залежно від способу формування. Висвітлено дискусійне питання стосовно доцільності надання приватним організаціям можливості розроблення землевпорядної документації нарівні із державними органами. Приділено увагу особливостям розмежування юрисдикції органів, що вирішують земельні спори залежно від предмета спору, їх суті, характеру спірних правовідносин та суб'ектного складу. Також розглянуто практику розмежування юрисдикцій судів у земельних спорах з урахуванням позиції Верховного суду.
\end{abstract}

Ключові слова: земельні відносини, земельні спори, формування земельної ділянки.

Kushnir Victoria

Yaroslav Mudryi National Law University

\section{CERTAIN ASPECTS OF CONSIDERATION OF LAND DISPUTES ARISING DURING THE FORMATION OF LAND PLOTS}

Summary. The article is devoted to the research of issues related to certain aspects of consideration and resolution of land disputes, arising during the formation of land plots. The author draws attention to the fact that the legally meaningful features of land plots as well as their division on physical and legal features has been researched. In defining the concept of "land plots", the author identified four main features. In accordance, a "land plot" is a portion of the earth's surface with established boundaries and a particular location and to which there are defined rights. Special attention in the article is paid to the analysis of the procedure for forming a land plot. Analyzing the formation of land, the author notes the existence of different procedures for the formation of land plot. Considerable attention is paid to the consideration of a clear sequence of actions in order to form a land plot. After all actions in aggregate form an algorithm, the execution of which leads to the desired effect. Considering the procedure of land formation, the author in his article also examines the most interesting on the topic of the article of the Resolution of the Supreme Court of Ukraine for the last few years. This article also considers which organizations have the right to develop land management documentation. According to the author, the practice of preparing land management documentation by private organizations has a number of disadvantages and risks, and therefore it is necessary that only specially authorized public authorities prepare land management documentation. The article examined the actual problem, namely, administrative and legal foundations of judicial protection of property rights to land. The author considers the jurisdiction of cases arising from land relations to the commercial, civil or administrative court, taking into account the subject composition, subject matter of the dispute and the nature of the disputed legal relationship. Based on the analysis of judicial practice, it is emphasized on the need to follow the procedure established by law is emphasized in order to successfully exercise the rights.

Keywords: land disputes, consideration of land disputes, land plots.

$\Pi$ остановка проблеми. Статтею 14 Конституції України встановлено, що земля $є$ основним нащіональним багатством, що перебуває під особливою охороною держави. Право власності на землю гарантується. Це право набувається і реалізуеться громадянами, юридичними особами та державою виключно відповідно до закону. Особливе місце у процесі реалізації та захисту земельних прав є вирішення земельних спорів, яке здійснюеться компетентними органами у встановленому законом порядку, а існування правового інституту вирішення земельних спорів можна вважати одним із різновидів гарантій прав на землю.

Враховуючи те, що Україна є однією з найбільших европейських країн за територією та має високий рівень розораності земель, забезпечення належного правового регулювання розгляду і вирішення земельних спорів $є$ необхідним у демократичному суспільстві засобом захисту прав людини, у тому числі їі земельних прав.
Аналіз останніх досліджень і публікацій. Окремі аспекти вирішення земельних спорів є предметом наукових досліджень багатьох вітчизняних та зарубіжних вчених. Серед численної кількості наукових досліджень на особливу увагу заслуговують праці таких вчених: Каракаша I.I. [1], Шульги М.В. [2], Дремлюги К.О. [3], Одарюка М.П. [5] Поліщука О.Г. [8], Сидор В.Д. [9], та інші. Комплексному дослідженню питання земельних спорів та процедур, пов'язаних з правовим регулюванням їх вирішення присвячена монографрія Лейби Л.В. [15].

Метою даної статті $є$ висвітлення питання розв'язання земельних спорів, зокрема під час формування земельних ділянок, а також визначення розмежування юрисдикщії органів, що вирішують земельні спори з урахуванням практики Верховного суду.

Виклад основного матеріалу. Чинне земельне законодавство не містить офіційного визначення поняття «земельного спору». Тому 
у науковій літературі можна знайти різні визначення даної категорії. Проте, враховуючи норми Земельного кодексу України, зокрема положення Глави 25, під земельними спорами слід розуміти неврегульовані розбіжності, що пов'язані із застосуванням норм земельного законодавства щодо володіння, користування і розпорядження земельними ділянками та реалізацією інших прав на землю, які виникають між суб'ектами земельних відносин i підлягають вирішенню у порядку, встановленому законом [1, с. 134]. Наведене визначення земельного спору, було сформоване Каракашем I.I., однак враховуючи те, що вирішення земельних спорів є важливою гарантією захисту прав на землю, доцільно було б припинити наукову дискусію з цього питання і закріпити нормативне визначення.

Однією із поширених категорій земельних спорів є спори, що виникають під час проведення процедури формування земельних ділянок. Перш за все, необхідно розглянути поняття «земельна ділянка", адже у науці земельного права щодо тлумачення відповідного поняття існують різні думки. Наприклад, М.В. Шульга визначає земельну ділянку як частину поверхні земного грунту, яка $є$ основою ландшафру, має фріксовану площу, межі та місцезнаходження [2, с. 13]. У свою чергу, Дремлюга К.О. вважає, що у ст. 79 ЗКУ закріплено не всі суттеві ознаки земельної ділянки і визначає її як частину земної поверхні з визначеними в натурі (на місцевості) межами, фріксованим розміром та сталим (нерухомим) місцем розташування, яка характеризуеться цільовим призначенням, фрункціональним використанням та специфічним правовим режимом, що визначаються 3 урахуванням їі природних якостей та фізичних властивостей [3, с. 201]. Відповідно до ч. 1 ст. 79 ЗК України, земельна ділянка - це частина земної поверхні з установленими межами, певним місцем розташування, 3 визначеними щодо неї правами [4]. Таким чином, законодавець пов'язуе це поняття з такими істотними ознаками, як: 1) частина земної поверхні; 2) установлені межі; 3) певне місце розташування; 4) визначені щодо неї права.

Індивідуалізуючою ознакою земельної ділянки, яка допомагає локалізувати їі та відокремити від інших земельних ділянок є їі місце розташування. Однак визначення меж та встановлення місця розташування земельної ділянки ще не перетворюе іï на предмет земельних правовідносин [5, с. 34]. Аналізуючи ст. 79-1 ЗК України, доходимо висновку, що місце розташування земельної ділянки визначаеться при іiі формуванні, яке передбачає визначення ії площі, меж та внесення інформащії про неї до Державного земельного кадастру. Сформовані земельні ділянки підлягають державній реєстрації у Державному земельному кадастрі. Земельна ділянка вважається сформованою 3 моменту присвоєння їй кадастрового номера. Під ним розуміеться індивідуальна, що не повторюється на всій території України, послідовність џифр та знаків, яка присвоюється земельній ділянці під час iii державної реєстрації і зберігається за нею протягом усього часу існування (ст. 1 Закону України «Про державний земельний кадастр») [6].

Аналізуючи формування земельних ділянок, варто зауважити, що в залежності від того, яким шляхом та в якому порядку воно здійснюеться, ч. 2 статті 79-1 3К України фрактично визначає різні процедури проведення фрормування земельних ділянок. Формування земельних ділянок здійснюеться за проєктами землеустрою, крім випадків, формування їх шляхом поділу чи об єднання раніше срормованих ділянок, що в свою чергу здійснюється за технічною документацією із землеустрою щодо поділу та об єднання земельних ділянок.

Принциповою у даному питанні $є$ позиція Касаційного адміністративного суду Верховного суду України, висвітлена у справі № 804/3108/16 від 15.09.2020. Правова позиція КАС/ВС полягає в тому, що проєкт землеустрою щодо відведення земельних ділянок та технічна документащія із землеустрою щодо поділу та об єднання земельних ділянок є різними за своєю суттю документами із землеустрою, не $\epsilon$ тотожними за процедурою виконання цієї документації. Адже на одній частині земної поверхні неможливим $є$ існування двох одночасно зареєстрованих земельних ділянок, координати яких перетинаються, оскільки частина 2 статті 79 Земельного кодексу України встановлює, що право власності на земельну ділянку поширюеться в їі межах на поверхневий шар. Отже, надання дозволу на розробку проєкту землеустрою має на меті лише формування земельної ділянки як окремого об єкта. Натомість, коли йдеться про формування земельної ділянки 3 частини вже сорормованого земельного масиву, що має ка-

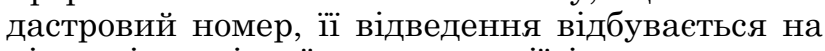
підставі технічної документації із землеустрою щодо поділу земельної ділянки [7].

Особа, зацікавлена в одержанні у користування земельної ділянки із земель державної або комунальної власності за проєктом землеустрою щодо їі відведення, звертається з клопотанням про надання дозволу на його розробку до відповідного органу виконавчої влади або органу місцевого самоврядування, які відповідно до повноважень, визначених статтею 122 ЗК України, передають у власність або користування такі земельні ділянки [4]. У клопотанні зазначаються орієнтовний розмір земельної ділянки та їі цільове призначення. До клопотання додаються графрічні матеріали, на яких зазначено бажане місце розташування та розмір земельної ділянки.

Відповідний орган виконавчої влади або орган місцевого самоврядування в межах їх повноважень у місячний строк розглядає клопотання і дає дозвіл на розроблення проєкту землеустрою щодо відведення земельної ділянки або надає мотивовану відмову у його наданні. Забороняється відмова у наданні дозволу на розробку проєкту землеустрою щодо відведення земельних ділянок, місце розташування об'єктів на яких погоджено відповідним органом виконавчої влади або органом місцевого самоврядування згідно із статтею 151 Земельного Кодексу [4]. У разі якщо у місячний строк 3 дня реєстращії клопотання зацікавленій особі не було надано дозвіл на розроблення документації із землеустрою або мотивовану відмову у його наданні, то така особа, у місячний строк 3 дня закінчення зазначеного строку має право замовити розроблення документації із землеустрою без отримання дозволу, 
але $з$ обов'язковим повідомленням відповідного органу. Законодавчо передбачена можливість розроблення документації із землеустрої без дозволу відповідного органу виконавчої влади чи органу місцевого самоврядування слугує додатковою гарантією для зацікавлених осіб від навмисного затягування процесу формування земельної ділянки.

Варто зазначити, що навіть у випадку, якщо суд визнає неправомірною відмову у наданні дозволу на розроблення проєкту землеустрою може виникнути ситуація, коли позивачі після розроблення проєктів землеустрою щодо відведення спірних земельних ділянок будуть позбавлені можливості отримати у власність ці земельні ділянки, тобто очікування та затрати позивачів будуть невиправданими. Тому необхідно враховувати, що відповідно до практики Верховного Суду, отримання дозволу на розробку проєкту землеустрою щодо відведення земельної ділянки не гарантує отримання в подальшому позитивного рішення про передачу такої земельної ділянки особі. Така правова позиція викладена у Постановах Верховного Суду України від 19 січня 2016 року № 21-3690а15, від 13 грудня 2016 року № 21-2573a16 та інших [8, с. 127].

Доречною з цього приводу є думка Сидор В.Д., яка вважає відносини щодо формування земельних ділянок одними 3 найбільш проблемних з точки зору їх реалізації. Передовсім, значними $\epsilon$ часові та грошові витрати при здійсненні землевпорядних дій. Це, у свою чергу, ускладнює набуття і реалізацію законних прав на землю, створюе суттеві труднощі під час захисту цих прав. Одним із результатів перетворень у галузі землеустрою, як вважає науковець, виступає те, що виконавчі органи державної влади звільняються від проведення землевпорядних дій, які, по суті, відносяться до фрункцій органів публічної влади, передаючи їх проведення приватним особам і організаціям. До речі, чинне законодавство передбачає можливість проведення землевпорядних дій будь-якими особами, якщо вони відповідають встановленим вимогам. За таких умов землеустрій перестає бути тільки однією з функцій управління у сорері використання і охорони землі, а стає видом комерційної діяльності [9, с. 326].

Як свідчить практика, розроблення землевпорядної документації приватними організаціями часто може мати негативні наслідки. Аргументація того, що перетворення землевпорядної діяльності на один із видів комерційної діяльності $є$ більш зручним та швидким способом для громадян підготувати необхідні документи втрачає свій сенс, якщо замислитися над питанням: а яку ж саме землевпорядну організащію обрати. Наразі у Державному реєстрі сертифрікованих інженерів-землевпорядників міститься 5694 записи про фрізичних осіб, які пройшли процедуру сертифікації та отримали кваліфрікаційний сертифрікат для надання послуг зі складання землевпорядної документації. Але якість виконання робіт приватними суб'єктами при розробленні документаціі із землеустрою доволі часто не відповідає очікуванням замовника. Першочерговою ціллю комерційної діяльності є отримання прибутку, у зв'язку 3 чим деякі приватні землевпорядні організації жертвують своєю репутацією та якістю виконання послуги на користь збільшення обсягів прибутків. Однією із найбільш поширених причин відмови громадянам у реєстрації земельної ділянки $\epsilon$ саме помилки землевпорядних організацій. Все це значно затягуе процес реєстраціі, а також потребуе додаткових витрат, адже часто навіть не зважаючи на те, що особі розробили неякісну землевпорядну документацію, яку не пропускає автоматизована система кадастру, землевпорядники відмовляються виправити свої помилки і вимагають додаткову платню.

На підтвердження позиції стосовно того, що розроблення землевпорядної документації має бути прерогативою саме органів державної влади, свідчить також судова практика. Зокрема, Piшення Господарського суду Хмельницької області від 31.01.2019. Щодо суті справи, то позивач сплатив на користь відповідача (землевпорядної організації) вартість виготовлення технічної документацій із землеустрою ще 03.08.2015 р. Однак, станом на 20.12.2018 р. відповідач так і не підготував документацію, посилаючись на те, що ним все ще вчиняються дії щодо виконання умов договору. Зважаючи на те, що ст. ст. 28, 55 Закону України «Про землеустрій», в редакції станом на 03.08.2015 р., передбачено максимальний строк складання документації із землеустрою, котрий не повинен перевищувати шести місяців з моменту укладення договору, суд частково задовільнив вимоги позивача [10]. Таким чином стає очевидним, що навіть задоволення позову не зможе повністю компенсувати шкоду, заподіяну інтересам замовника землевпорядної документації, а тим більше повернути втрачений час через недобросовісність приватної організації.

Сдиною підставою для відмови у затвердженні проєкту землеустрою може бути лише те, що проєкт землеустрою не погоджено в порядку, встановленому статтею 186-1 Земельного кодексу, а також відсутність обов'язкової державної експертизи у визначених законом випадках та відомостей щодо державної реєстрації сорормованої земельної ділянки у Державному земельному кадастрі [6]. Жодних інших правових підстав для відмови у затвердженні проєкту землеустрою після його погодження в порядку статті 186-1 Земельного кодексу України, норми статті 118 Земельного кодексу не містять. При цьому перевірка на відповідність проєкту землеустрою вимогам законів та прийнятих відповідно до них нормативно-правових актів має здійснюватися саме на етапі погодження такого проєкту [4]. У випадку, коли особа вважає відмову у затверджені чи погодженні проєкту землеустрою неправомірною, то вона оспорюе рішення суб'єкта владних повноважень, який здійснював владні управлінські фонкції, а тому цей спір відноситься до юрисдикції адміністративного суду.

Враховуючи те, що розмежування компетенції органів, що вирішують земельні спори, залежно від предмета спору, їх суті, характеру спірних правовідносин та суб'єктного складу не позбавлене наукової дискусії, доцільно більш детально зупинитися на цьому питанні. Відповідно до ч. 1 ст. 158 Земельного кодексу, земельні спори вирішуються судами, органами місцевого самоврядування та центральним органом виконавчої влади, що реалізує державну політику 
у сфері земельних відносин. При цьому у наведеній нормі певною мірою передбачаеться розмежування компетенції вказаних органів стосовно вирішення земельних спорів. Так, виключно судом вирішуються земельні спори з приводу володіння, користування і розпорядження земельними ділянками, що перебувають у власності громадян і юридичних осіб, а також спори щодо розмежування територій сіл, селищ, міст, районів та областей [4]. Органи місцевого самоврядування вирішують земельні спори у межах населених пунктів щодо меж земельних ділянок, що перебувають у власності і користуванні громадян, та додержання громадянами правил добросусідства, а також спори щодо розмежування меж районів у містах. Центральний орган виконавчої влади, що реалізуе державну політику у сфері земельних відносин, вирішуе земельні спори щодо меж земельних ділянок за межами населених пунктів, обмежень у використанні земель та земельних сервітутів.

Вирішення земельних спорів органами місцевого самоврядування або центральним органом виконавчої влади не позбавляе учасників спору права на звернення до суду. У зв'язку з цим актуальним е питання до якого саме суду звертатися залежно від суб'єктного складу учасників земельного спору. Практика розмежування юрисдикцій судів у земельних спорах часто буває суперечливою, навіть рішення прийняті на касаційному рівні не завжди є однозначними. Так, у п. 1.2.2 постанови пленуму Вищого господарського суду «Про деякі питання практики розгляду справ у споpax, що виникають із земельних відносин» від 17.05.2011 № 6 зазначено, що органи виконавчої влади чи місцевого самоврядування у правовідносинах щодо розпорядження ділянками державної та комунальної власності діють як органи, через які держава або територіальна громада реалізуе повноваження власника цих ділянок. Тому спори за їх участю, а також інші спори, які виникають із земельних відносин приватноправового характеру, за відповідного складу сторін підвідомчі саме господарським судам [11].

Згодом у п. 7 постанови пленуму Вищого спеціалізованого суду з розгляду цивільних і кримінальних справ «Про деякі питання юрисдикції загальних судів та визначення підсудності цивільних справ" від 01.03.2013 було вказано, що спори, котрі виникають із земельних відносин, в яких хоча б однією зі сторін $е$ фізична особа, незважаючи на участь у них суб'єкта владних повноважень, розглядаються за правилами цивільного судочинства [12]. Зокрема, це стосуеться позовів про визнання недійсними рішень органів виконавчої влади, органів місцевого самоврядування стосовно видання дозволу на розроблення проекту землеустрою, вирішення інших питань, які відповідно до закону необхідні для набуття та реалізації прав на землю тощо.

Проте, не минуло і трьох місяців, як у п. 12 постанови пленуму Вищого адміністративного суду «Про окремі питання юрисдикції адміністративних судів» від 20.05.2013 № 8 з'явилося протилежне твердження. Зокрема, що управління та розпорядження державним і комунальним майном $e$ організаційно-правовою діяльністю суб'єктів владних повноважень. Тому на земель- ні спори фізичних чи юридичних осіб з органом місцевого самоврядування як суб'єктом владних повноважень, що пов'язані з оскарженням його рішень, дій чи бездіяльності, поширюеться юрисдикція адміністративних судів [13].

На розгляд Верховної ради було подано проєкт Закону «Про внесення змін до Господарського процесуального кодексу України щодо підвідомчості спорів, що виникають у сфері земельних відносин та спорів щодо нерухомого майна» № 3296 від 31.03.2020, котрий на даний момент опрацьовується в комітеті [14]. Даним законопроєктом пропонуеться віднести справи у спорах, що виникають у сфері земельних відносин, до юрисдикщії господарських судів, за невеликим винятком, незалежно від складу учасників провадження. Прийняття даного законопроекту є необхідним задля остаточного усунення юрисдикційних суперечностей. Це також є важливим з огляду на те, що порушення правил підсудності може призвести до скасування рішення судом вищої інстанщії.

Таким чином, можна дійти висновку, що справи зі спорів про оскарження рішень органів державної влади та місцевого самоврядування щодо їхніх повноважень зі здійснення землеустрою, якщо підставою спорів е, зокрема, відмова у затвердженні проєкту землеустрою щодо відведення земельної ділянки та скасування раніше прийнятого місцевою радою рішення про надання особі дозволу на розробку проєкту землеустрою, порушення органом місцевого самоврядування порядку та строків надання дозволу на розробку проекту із землеустрою, за умови якщо на ділянку не встановлено речового права позивача - dpiзичної особи або третіх осіб, підлягають розгляду у порядку адміністративного судочинства.

У свою чергу, юрисдикція справ зі спорів зазначеної вище категорії справ, у яких судами встановлено наявність речового права на земельну ділянку залежатиме від того, яке рішення прийнято суб’ектом владних повноважень: у разі прийняття акту індивідуальної дії спір підлягатиме розгляду у порядку цивільного судочинства, а у разі прийняття нормативно-правового акту - в порядку адміністративного судочинства [15, с. 14].

Висновки. Чітке дотримання законодавчо закріпленої процедури формування земельної ділянки є запорукою успішної реалізації своїх земельних прав та допоможе уникнути зайвих витрат як коштів, так і часу. У випадку наявності перешкод 3 боку органів виконавчої влади, органів місцевого самоврядування, інших землевласників важливо вірно визначати орган, якому підвідомче вирішення конкретного земельного спору. Однак, питання визначення юрисдикції не завжди є очевидним і підхід судів час від часу може змінюватися. Виходячи з правових висновків ВП Верховного Суду, в кожній конкретній справі необхідно аналізувати у сукупності суб’єктний склад, предмет спору та характер спірних правовідносин. Зокрема, для віднесення спору про оскарження рішення органу місцевого самоврядування до юрисдикції цивільного чи господарського суду визначальним е наявність спору про право. У справах адміністративної юрисдикції необхідно визначити, діе орган місцевого самоврядування як суб'ект владних повноважень або реалізуе в правовідносинах права власника майна. 


\section{Список літератури:}

1. Каракаш I.I. Правове регулювання розгляду та вирішення земельних спорів як гарантія захисту прав на землю. Підприелництво, господарство і право. 2017. С. 132-138.

2. Шульга М.В. Актуальные проблемы правового регулирования земельних отношений в современных условиях : дис. докт. юрид. наук : 12.00.06. Харьков, 1998. С. 29.

3. Дремлюга К.О. Підстави набуття прав на землю громадянами України : дис. канд. юрид наук : 12.00.06. Івано-Франківськ, 2010. 212 с.

4. Земельний кодекс України від 25.10.2001 p. № 2768-III. URL: http://zakon.rada.gov.ua/laws/show/2768-14 (дата звернення: 20.03.2021).

5. Одарюк М.П. Щодо юридичної природи процедур у земельному праві. Наукові записки Інституту законодавства Верховної Ради Украӥни. 2017. № 7. С. 62-70.

6. Про Державний земельний кадастр : Закон України від 07.07.2011 р. № 3613-VI. Відомості Верховної Ради України. 2012. № 8. С. 61.

7. Постанова від 15.09.2020 № 804/3108/16 Верховний Суд. Касаційний адміністративний суд. URL:https://verdictum.ligazakon.net/document/91722445?utm_source=jurliga.ligazakon.ua\&utm_medium=news\& utm_content=j103 (дата звернення: 18.03.2021).

8. Поліщук О.Г. Окремі проблеми правового регулювання проведення земельних торгів. Європейські перспективи. 2013. № 12. С. 99-124.

9. Сидор В.Д. Правова природа землеустрою. Держава і право. Юридичні і політичні науки. Київ : Ін-т держави і права ім. В.М. Корецького НАН України, 2013. Вип. 59. С. 325-330.

10. Рішення Господарського суду Хмельницької області № 79687546 від 31.01.2019. URL: https://youcontrol.com.ua/ ru/catalog/court-document/79687546/

11. Про деякі питання практики розгляду справ у спорах, що виникають із земельних відносин: постанова пленуму Вищого господарського суду України від 17 травня 2011 року № 6. Вісник господарського судочинства. 2011. № 3. C. 6.

12. Про деякі питання юрисдикції загальних судів та визначення підсудності цивільних справ : постанова пленуму Вищого спеціалізованого суду з розгляду цивільних і кримінальних справ від 01.03.2013. Bicник Вищого адміністративного суду України. 2013. № 1.

13. Про окремі питання юрисдикції адміністративних судів : постанова пленуму Вищого адміністративного суду України від 20 травня 2013 року № 8. Вісник Вищого адміністративного суду Украӥни. 2013. № 2.

14. Юридична Газета online. Зміни до ГПК щодо підвідомості спорів про нерухоме майно : законопроєкт у Раді. 03 квітня 2020. URL: https://yur-gazeta.com/golovna/zmini-do-gpk-shchodo-pidvidomosti-sporiv-pro-neruhomemayno-zakonoproekt-u-radi.html (дата звернення: 18.03.2021).

15. Лейба Л.В. Земельні спори і порядок їх вирішення : монографія / за ред. проф. М.В. Шульги. Харків : Право, 2007. $160 \mathrm{c}$.

\section{References:}

1. Karakash I.I. (2017) Pravove rehuliuvannia rozghliadu ta vyrishennia zemelnykh sporiv yak harantiia zakhystu prav na zemliu. Pidpryiemnytstvo, hospodarstvo i pravo.

2. Shulha M.V. (1998) Aktualnye problemy pravovoho rehulyrovanyia zemelnykh otnoshenyi v sovremennykh uslovyiakh: Dys. dokt. yuryd. nauk: 12.00.06. Kharkov.

3. Dremliuha K.O. (2010) Pidstavy nabuttia prav na zemliu hromadianamy Ukrainy: Dys. kand. yuryd nauk: 12.00.06. Ivano-Frankivsk.

4. Zemelnyi kodeks Ukrainy vid 25.10.2001. no. 2768-III. URL: http://zakon.rada.gov.ua/laws/show/2768-14

5. Odariuk M.P. (2017) Shchodo yurydychnoi pryrody protsedur u zemelnomu pravi. Naukovi zapysky Instytutu zakonodavstva Verkhovnoi Rady Ukrainy, no. 7, pp. 62-70.

6. Pro Derzhavnyi zemelnyi kadastr: Zakon Ukrainy vid 07.07.2011 no. 3613-VI. Vidomosti Verkhounoi Rady Ukrainy, 2012, no. 8, pp. 61.

7. Postanova vid 15.09.2020 no. 804/3108/16 Verkhovnyi Sud. Kasatsiinyi administratyvnyi sud. URL:https://verdictum.ligazakon.net/document/91722445?utm_source=jurliga.ligazakon.ua\&utm_medium=news\& utm content=jl03

8. Polishchuk O.H. (2013) Okremi problemy pravovoho rehuliuvannia provedennia zemelnykh torhiv. Yevropeiski perspektyvy, no. 12, pp. 99-124.

9. Sydor V.D. (2013) Pravova pryroda zemleustroiu. Derzhava i pravo. Yurydychni i politychni nauky. Kyiv: In-t derzhavy i prava im. V.M. Koretskoho NAN Ukrainy, vol. 59, pp. 325-330.

10. Rishennia Hospodarskoho sudu Khmelnytskoi oblasti no. 79687546 vid 31.01.2019. URL: https://youcontrol.com.ua/ $\mathrm{ru} / \mathrm{catalog} / \mathrm{court}$-document/79687546/

11. Pro deiaki pytannia praktyky rozghliadu sprav u sporakh, shcho vynykaiut iz zemelnykh vidnosyn: postanova plenumu Vyshchoho hospodarskoho sudu Ukrainy vid 17 travnia 2011 roku no. 6. Visnyk hospodarskoho sudochynstva, 2011, no. 3, p. 6.

12. Pro deiaki pytannia yurysdyktsii zahalnykh sudiv ta vyznachennia pidsudnosti tsyvilnykh sprav: postanova plenumu Vyshchoho spetsializovanoho sudu z rozghliadu tsyvilnykh i kryminalnykh sprav vid 01.03.2013. Visnyk Vyshchoho administratyvnoho sudu Ukrainy, 2013, no. 1.

13. Pro okremi pytannia yurysdyktsii administratyvnykh sudiv: postanova plenumu Vyshchoho administratyvnoho sudu Ukrainy vid 20.05. 2013 no. 8. Visnyk Vyshchoho administratyunoho sudu Ukrainy, 2013, no. 2.

14. Yurydychna Hazeta online. Zminy do HPK shchodo pidvidomosti sporiv pro nerukhome maino: zakonoproekt $u$ Radi. 03.04.2020. URL: https://yur-gazeta.com/golovna/zmini-do-gpk-shchodo-pidvidomosti-sporiv-pro-neruhomemayno-zakonoproekt-u-radi.html

15. Leiba L.V. (2007) Zemelni spory i poriadok yikh vyrishennia: monohrafiia / za red. prof. M.V. Shulhy. Kharkiv: Pravo. 